\title{
CALL FOR PROPOSALS
}

\section{$58^{\text {th }}$ Annual Meeting of the African \\ $\Longrightarrow$ Studies \\ Association \\ THE STATE AND STUDY OF AFRICA}

NOVEMBER 19-22, 2015 • SHERATON SAN DIEGO HOTEL AND MARINA

\section{DEADLINE FOR PROPOSAL SUBMISSION:}

March 15, 2015

\section{PROGRAM CHAIRS}

Derek R. Peterson, University of Michigan

Dismas A. Masolo, University of Louisville

\begin{abstract}
About the Meeting
We are soliciting proposals for papers, panels, and roundtables. Presentations may focus on the theme of The State and Study of Africa or on broader social science, humanities, and applied themes relating to Africa. We strongly encourage the submission of formed panels. You can find more information on the theme and the call for proposals at the ASA website, www.africanstudies.org.
\end{abstract}

\section{How to Submit a Proposal}

Instructions for submitting proposals can be found online on the ASA website, www.africanstudies.org.

\begin{abstract}
About the
African Studies Association

Established in 1957, the African Studies

Association is the largest organization in the

world devoted to enhancing the exchange

of information about Africa. Our members

include scholars, students, teachers, activists,

development professionals, policy makers, donors and many others. We encourage interdisciplinary interactions with Africa. We provide access to pathbreaking research and key debates in African studies. We bring together people with scholarly and other interests in Africa through our annual meeting and seek to broaden professional opportunities in the field of African studies. The organization publishes two leading interdisciplinary journals on Africa, African Studies Review and History in Africa and promotes an informed understanding of Africa to the public and in educational institutions as well as to businesses, media, and other communities that have interests in Africa.
\end{abstract}

\author{
ENQUIRIES \\ asameeting2015@gmail.com
}

Follow the ASA on Twitter, @ASANewsOnline, for updates on the Annual Meeting 


\section{Instructions for Contributors}

International Journal of Cultural Property is a peer-reviewed journal which publishes papers and other materials representing a broad set of perspectives on problems relating to cultural property, cultural heritage, and related issues. Contributions are welcome from the wide variety of fields implicated in the debates-law, anthropology, public policy, archaeology, art history, preservation, museum-, tourism-, and heritage studies-and from a variety of perspectives and interests-indigenous, Western, and non-Western; academic, professional and amateur; consumers and producers - to promote meaningful discussion of the complexities, competing values, and other concerns that form the environment within which these disputes exist.

The IJCP accepts contributions in English (though exceptions may be made) of two types:

Articles should be sent to the Editor, preferably by email to culturalproperty@ cambridge.org (or mailed to Alexander Bauer, Department of Anthropology, Queens College, 65-30 Kissena Blvd., Flushing, NY 11367), and may address any issue regarding tangible or intangible cultural property and heritage, and may draw upon scholarship from such diverse fields as anthropology, archaeology, economics, geography, law, museum studies, public policy, and tourism management, among others. Because of the interdisciplinary nature of the subject matter, authors should refrain from employing subject-specific jargon where possible, and should generally keep in mind that diverse readership may require that certain concepts be explained in greater detail than they are accustomed. Of particular interest are articles which contain a pragmatic dimension and propose new directions for policy and practice. Submitted manuscripts should generally be between 6000 and 9000 words, although longer pieces may be considered, and should follow the format described in the "Instructions for Contributors" printed in Vol. 20, No. 1 (2013) and available online at http://www.journals.cambridge.org/jid_JCP.

Case Notes should be sent directly to the Case Notes Editor either by email at paterson@ law.ubc.ca or mail (to Robert Paterson, University of British Columbia Law School) and may deal with national, state or provincial court decisions, decisions of international or administrative tribunals, and other decision-making bodies, such as arbitration tribunals. They should not exceed 6000 words in length except in exceptional circumstances, and should set out the facts of the case under discussion and summarize the reasoning of the court or other decision-making body, making reference to similar earlier cases, as well as contain critical discussion of the findings in the case. In general, Case Notes should contain all available citations for the case being discussed, both official and unofficial and electronic wherever possible. In the case of decisions that are not available in English authors should be particularly aware that readers may not be able to read the actual decision and provide more information about the facts and reasoning in the case than might otherwise seem necessary.

Aside from the above materials, the IJCP also publishes book reviews, documents of record, chronicles (a summary of significant national and regional developments) and conference reports. Books to be considered for review should be sent directly to the Book Review Editor (Patrick O’Keefe, P.O. Box 8049, Toowoomba Mail Centre, Toowoomba Queensland 4352, Australia). Readers wishing to alert the IJCP about significant documents of record and upcoming conferences should contact the Chronicles Editor (Kurt Seihr, by mail to: Mittelweg 187, D 20148 Hamburg, Germany, or email to: siehr@mpipriv-hh.mpg.de).

For an expanded version of the Instructions for Contributors please see IJCP 20(2013): 129-132 or go to the journals website: www.Journals.cambridge.org. 


\title{
CONTENTS \\ VOLUME 21 (2014) NUMBER 4
}

\author{
ARTICLES \\ Territoriality and State Succession in Cultural Heritage \\ Andrzej Jakubowski \\ Protecting Holy Heritage in Italy - A Critical Assessment through the Prism of \\ International Law \\ Alessandro Chechi
}

South Carolina's Tidal Rice Fields: Consultation, Collaboration, and Cultural Landscapes Jodi A. Barnes and Rebekah Dobrasko

From Babylon to Baghdad: Cultural Heritage and Constitutional Law in the Republic of Iraq Tess Davis

"A Fracture in Time": A Cup Attributed to the Euaion Painter from the Bothmer Collection Christos Tsirogiannis and David W. J. Gill

The Draft Convention on Immunity from Suit and Seizure for Cultural Objects Temporarily Abroad for Cultural, Educational or Scientific Purpose

Nout van Woudenberg and James A. R. Nafziger 